\title{
Assessing fidelity to complex interventions: the icons experience
}

\author{
Brigit Chesworth ${ }^{1 *}$, Michael Leathley ${ }^{1}$, Lois Thomas ${ }^{1}$, Denise Forshaw ${ }^{1}$, Chris Sutton ${ }^{1}$, Bev French ${ }^{1}$, Chris Burton ${ }^{3}$, \\ David Britt ${ }^{1}$, Brenda Roe ${ }^{2}$, Francine Cheater ${ }^{4}$, Caroline Watkins ${ }^{1}$ \\ From 2nd Clinical Trials Methodology Conference: Methodology Matters \\ Edinburgh, UK. 18-19 November 2013
}

\section{Background}

Assessing fidelity to complex healthcare interventions in clinical trials is a challenging area. 'ICONS' is a cluster randomised controlled feasibility trial of a systematic voiding programme (SVP), incorporating bladder training and prompted voiding, to promote post-stroke continence. Here we describe feasibility of one aspect of fidelity assessment: the day-to-day implementation of the SVP through analysis of clinical logs.

\section{Methods}

Nurses completed clinical logs daily, which included documenting: the toileting interval, proposed toileting times and times toileted. Clinical logs were sampled across trial sites. The original intention was to assess fidelity by exploring the degree of concordance between proposed times and times toileted. Initial analysis revealed the unfeasibility of this method due to documentation errors in toileting intervals and proposed times. Consequently, the planned method was changed to identification of key 'quality indicators' (QIs) for documentation of practice.

\section{Results}

The need to revise the method of measurement demonstrates the difficulty in assessing fidelity. Assessment of clinical logs revealed low levels of adherence to key quality indicators. However, it is unclear whether this indicates poor fidelity or an imprecise method of fidelity assessment.

\section{Conclusion}

This study highlights challenges of assessing fidelity to complex interventions. Lessons learned will inform the measurement of fidelity in a future trial. Researchers

${ }^{1}$ University of Central Lancashire, Preston, UK

Full list of author information is available at the end of the article should be aware that the practical implementation of complex healthcare interventions may not be exactly as intended. For ICONS, clinical logs constituted a proxy measure of day-to-day fidelity to the intervention: identification of alternative methods could be considered.

\section{Authors' details}

'University of Central Lancashire, Preston, UK. ${ }^{2}$ Edge Hill University, Ormskirk, UK. ${ }^{3}$ Bangor University, Bangor, UK. ${ }^{4}$ University of East Anglia, Norwich, UK.

Published: 29 November 2013

doi:10.1186/1745-6215-14-S1-P4

Cite this article as: Chesworth et al:: Assessing fidelity to complex interventions: the icons experience. Trials 2013 14(Suppl 1):P4.
Submit your next manuscript to BioMed Central and take full advantage of:

- Convenient online submission

- Thorough peer review

- No space constraints or color figure charges

- Immediate publication on acceptance

- Inclusion in PubMed, CAS, Scopus and Google Scholar

- Research which is freely available for redistribution

Submit your manuscript at www.biomedcentral.com/submit
() Biomed Central

\section{() Biomed Central}

